\title{
Analisis Kondisi Kesehatan Ikan Patin Pangasius sp. yang Terinfeksi Bakteri Edwardsiella tarda
}

\section{Health Condition Analysis of Catfish Pangasius sp. Infected by Edwardsiella tarda Bacteria}

\author{
Qurrota A'yunin $^{1 *}$, Budianto ${ }^{1}$, Sri Andayani ${ }^{1}$ dan Dwi Candra Pratiwi ${ }^{2}$ \\ ${ }^{1}$ Program Studi Budidaya Perairan, Fakultas Perikanan dan Ilmu Kelautan, Universitas Brawijaya, Jl. \\ Veteran, Ketawanggede, Lowokwaru, Malang 65145, Indonesia \\ ${ }^{2}$ Program Studi Ilmu Kelautan, Fakultas Perikanan dan Ilmu Kelautan, Universitas Brawijaya, Jl. \\ Veteran, Ketawanggede, Lowokwaru, Malang 65145, Indonesia
}

\author{
*Correspondence : \\ qurrota_ayunin@ub.ac.id \\ Received : 2019-11-20 \\ Accepted : 2020-02-18 \\ Kata Kunci : \\ Budidaya Ikan, Hematologi, \\ Penyakit, Sistem Imun \\ Keywords : \\ Fish Culture, Haematology, \\ Disease, Immune System.
}

\begin{abstract}
Abstrak
Penyakit infeksi menjadi satu masalah yang masih sering timbul pada budidaya ikan patin. Salah satu penyakit yang sering timbul dalam budidaya ikan patin adalah penyakit MES (Motile Edwardsiella Septicemia) atau yang biasa dikenal dengan Edwardsielliosis. Penyebab penyakit MES adalah adanya infeksi dari bakteri Edwardsiella tarda. Bakteri E. tarda merupakan bakteri patogen yang memiliki dampak negatif bagi budidaya ikan air tawar. Tujuan penelitian ini adalah untuk mengetahui kondisi kesehatan ikan patin yang terinfeksi Bakteri E. tarda. Metode yang digunakan dalam penelitian ini diantaranya yaitu isolasi dan identifikasi bakteri, uji patogenitas, dan imunogenitas. Analisis darah dilakukan untuk mengetahui kondisi kesehatan ikan yang terinfeksi bakteri E. tarda. Sampel ikan patin diambil dari pembudidaya ikan di Kabupaten Sidoarjo. Hasil identifikasi isolat bakteri dari ikan patin menggunakan uji biokimia diperoleh ikan positif terinfeksi Bakteri Edwardsiella tarda. Kondisi kesehatan ikan dapat dilihat melalui pemeriksaan darah meliputi eritrosit, leukosit, diferensial leukosit (limfosit, monosit, dan neutrofil) dengan hasil 2,480 \pm 0.032 ; $3,460 \pm 0.087 ; \quad 80,38 \pm 0.34 ; 12,85 \pm 0.12 ;$ dan $6,77 \pm 0.28$ secara berturut-turut pada ikan patin normal, sedangkan pada ikan patin yang terinfeksi bakteri $E$. tarda yaitu $1,695 \pm 0,041 ; 7,795 \pm 0,095 ; 52,15 \pm 0.26 ; 33,61 \pm 0.52$; dan $14,24 \pm 0.47$ secara berturut-turut. Ikan patin yang terinfeksi bakteri Edwardsiella tarda menunjukkan kondisi kesehatan yang kurang baik, yang ditunjukkan dari peningkatan nilai leukosit, monosit, dan neutrofil sebagai bentuk respons kekebalan tubuh terhadap infeksi bakteri.
\end{abstract}

\section{Abstract}

Infection disease is a problem that still often arises in catfish culture. One of the diseases that often arise in catfish culture is MES (Motile Edwardsiella Septicemia) or 
commonly known as Edwardsielliosis. The cause of MES disease is an infection from the bacterium Edwardsiella tarda. E. tarda are pathogenic bacteria that harm freshwater fish farming. The purpose of this study was to determine the health condition of catfish infected with E. tarda bacteria. The methods used in this study include isolation and identification of bacteria, test for pathogenicity, and immunogenicity. Blood analysis was conducted to determine the health condition of fish infected with $E$. tarda bacteria. Catfish samples were taken from fish farmers in Sidoarjo District. The results of the identification of bacterial isolates from catfish by biochemical tests were positive fish infected with Edwardsiella tarda bacteria. Fish health conditions could be seen through blood tests including erythrocytes, leukocytes, differential leukocytes (lymphocytes, monocytes, and neutrophils) with the results of $2,480 \pm 0.032 ; 3,460 \pm$ $0.087 ; 80.38 \pm 0.34 ; 12.85 \pm 0.12$; and $6.77 \pm 0.28$, respectively in normal catfish, whereas in catfish infected with E. tarda bacteria that was $1.695 \pm 0.041 ; 7.795 \pm$ $0.095 ; 52.15 \pm 0.26 ; 33.61 \pm 0.52$; and $14.24 \pm 0.47$, respectively. The catfish infected with the bacterium Edwardsiella tarda exhibit poor health, as indicated by the increased values of leukocytes, monocytes, and neutrophils as forms of the body's immune response to bacterial infections.

\section{PENDAHULUAN}

Ikan patin (Pangasius sp.) merupakan ikan konsumsi air tawar unggulan yang banyak dibudidayakan. Berbagai upaya dilakukan untuk meningkatkan produksi ikan patin, salah satunya dengan intensifikasi budidaya. Namun, pengelolaan yang kurang tepat pada sistem budidaya intensif menyebabkan munculnya penyakit.

Infeksi penyakit menjadi satu masalah yang masih sering timbul pada budidaya ikan patin. Salah satu penyakit yang sering timbul dalam budidaya ikan patin adalah penyakit MES (Motile Edwardsiella Septicemia) atau yang biasa dikenal dengan edwardsielliosis. Penyebab penyakit MES adalah adanya infeksi dari bakteri Edwardsiella tarda. Bakteri E. tarda merupakan bakteri patogen yang memiliki dampak negatif bagi budidaya ikan air tawar. Infeksi E. tarda menimbulkan penurunan produktivitas budidaya ikan patin sehingga menyebabkan kerugian bagi pembudidaya (Oktafa et al., 2017). Penularan infeksi bakteri E. tarda terjadi secara horizontal yaitu melalui kontak antara inang satu dengan inang lainnya atau melalui air sebagai media budidaya (Tan et al., 2005).

Analisis darah perlu dilakukan untuk mengetahui kondisi kesehatan ikan yang terinfeksi bakteri E. tarda. Pengujian hematologi dilakukan untuk mengamati ketahanan tubuh atau gambaran sistem imun ikan terhadap organisme patogen serta tingkat infeksi suatu penyakit pada ikan (Sugiani et al., 2012). Pemeriksaan darah pada ikan meliputi leukosit, eritrosit, hematokrit, hemoglobin dan diferensial leukosit (neutrofil, limfosit dan monosit). Tujuan penelitian ini adalah untuk mengetahui kondisi kesehatan ikan patin yang terinfeksi Bakteri E. tarda. Menurut Nadirah et al. (2012), ikan yang terjangkit edwardsiellosis akan memperlihatkan gejala sebagai berikut: terjadi luka pada kulit yang kemudian akan meluas ke bagian daging, sehingga dengan segera akan mengakibatkan perdarahan. Luka semacam ini sering dijumpai pada hati 
ikan. Jika tidak segera diobati, luka-luka ini akan berkembang menjadi bisul dan mengeluarkan nanah (abses). Pada jaringan daging, hati dan ginjal sering terjadi nekrosis.

\section{METODOLOGI}

\section{Waktu dan Tempat}

Penelitian ini dilakukan pada bulan Oktober 2018 - April 2019 di Laboratorium Parasit dan Penyakit Ikan Universitas Brawijaya Malang, dan Balai Karantina Ikan Kelas I Juanda, Surabaya.

\section{Materi Penelitian}

Alat yang digunakan meliputi inkubator, oven, autoclave, neraca analitik, laminar flow, tabung reaksi, cawan petri, bunsen, erlemeyer, jarum ose, haemocytometer, spuit, pipet thoma eritrosit dan leukosit, object glass, dan cover glass. Sampel ikan didapatkan dari pembudidaya ikan.

Bahan yang digunakan adalah larutan Turk, media TSB (Tripticase Soy Broth), TSA (Tripticase Soy Agar), anti Koagulan (Na-sitrat 3.8\%), giemsa, larutan hayem, alkohol, metanol, sampel darah ikan, ginjal ikan, $\mathrm{H}_{2} \mathrm{O}_{2}$, oksidase strip, spiritus, covac indol, $\mathrm{KOH} \mathrm{40 \% ,} \alpha$ Naftol, methyl Red, parafin, TSI (Triple Sugar Iron) agar, Tryptophan broth, SIM medium, Lysin Iron Agar, MIO, O/F, Simmons Citrate Agar, urea, glukosa, maltosa, manitol, sorbitol, arabinosa, trehalosa, xilosa, nutrient agar, pereaksi pewarnaan gram, glukosa, sukrosa, kertas oksidase, dan akuades.

\section{Rancangan Penelitian}

Sampel ikan patin berasal dari pembudidaya ikan di Kabupaten Sidoarjo. Sampel yang digunakan berukuran \pm 200 gram. Sampel dimasukkan ke dalam coolbox yang berisi air dan dilengkapi aerator set, kemudian sampel dibawa ke laboratorium untuk diamati.

\section{Prosedur Kerja \\ Persiapan Hewan Uji}

Sampel ikan patin didapatkan dari pembudidaya ikan patin di Kabupaten Sidoarjo, Jawa Timur. Ikan patin yang diambil adalah ikan patin yang sehat dan ikan patin yang menunjukkan gejala klinis ikan sakit sebanyak 20 ekor. Menurut Hardi dan Handayani (2015), gejala klinis ikan yang terinfeksi patogen dapat diamati dari perubahan pola renang, tingkah laku makan, perubahan anatomi organ luar dan organ dalam.

\section{Inokulasi dan Identifikasi Bakteri $E$. tarda}

Bakteri diinokulasi dari organ target ikan seperti ginjal. Cara inokulasi bakteri yaitu dengan menggoreskan inoculation needle pada bagian ginjal dan ditanam pada media TSA. Hasil inokulan murni kemudian diidentifikasi secara biokimia.

\section{Pengambilan Sampel Darah}

Sampel darah ikan patin (Pangasius sp.) diambil dengan menggunakan spuit yang telah berisi Na Sitrat 3,8\% sebagai anti koagulan. Pengambilan sampel darah dilakukan pada bagian linea lateralis. Ikan disuntik dengan posisi jarum $45^{\circ}$ dan ditarik perlahan sampai darah masuk ke dalam spuit. Sampel darah dimasukkan ke dalam eppendorf.

\section{Pemeriksaan Hematologi \\ Perhitungan Jumlah Eritrosit}

Metode perhitungan jumlah eritrosit menurut Samsisko et al. (2013) diawali dengan pengambilan darah di mana ikan diletakkan dengan kepala di sebelah kiri. Spuit dibilas dengan NaSitrat 3,8\% yang berfungsi anti koagulan. Sampel darah diambil pada bagian linea lateralis menggunakan spuit $1 \mathrm{ml}$. Darah yang telah diambil, dimasukkan ke dalam tabung tube. Darah dihisap dengan pipet Thoma yang berisi bulir pengaduk warna merah sampai skala 0,5. Lalu ditambahkan larutan Hayem yang berfungsi untuk mematikan (melisiskan) 
sel. Kemudian dihomogenkan dengan cara mengayunkan tangan selama 3-5 menit. Tetesan pertama larutan darah dalam pipet Thoma dibuang, selanjutnya diteteskan pada haemacytometer tipe Neubauer yang telah ditutup dengan cover glass. Jumlah eritrosit dapat dihitung dengan rumus berikut (Nabib dan Pasaribu, 1989):

Eritrosit $=\frac{\mathrm{A}}{\mathrm{N}} \mathrm{x} \frac{\mathrm{L}}{\mathrm{V}} \mathrm{xFp}$

Keterangan:

A : $\Sigma$ sel terhitung

$\mathrm{V} \quad$ : Volume kotak haemocytometer

$\mathrm{N} \quad: \Sigma$ kotak haemocytometer yang diamati

Fp : Faktor Pengenceran

\section{Perhitungan Jumlah Leukosit}

Perhitungan jumlah leukosit diukur sesuai prosedur dari Blaxhall dan Daisley (1973). Pertama, darah sampel dihisap dengan pipet yang berisi bulir pengaduk berwarna putih sampai skala 0,5. Lalu, tambahkan larutan Turk sampai skala 11, pipet diayun membentuk angka 8 (sama dengan pengadukan untuk penghitungan jumlah sel darah merah) selama 3-5 menit sehingga darah bercampur rata. Setelah itu, dua tetes pertama larutan darah dari dalam pipet dibuang, selanjutnya larutan diteteskan pada haemocytometer, setelah itu ditutup dengan gelas penutup. Cairan akan memenuhi ruang hitung secara kapiler. Jumlah sel darah putih atau leukosit total dihitung dengan bantuan mikroskop dengan pembesaran 400x. Jumlah leukosit total dihitung dengan cara menghitung sel yang terdapat dalam 4 kotak kecil, dan jumlahnya dihitung menurut rumus :

Jumlah leukosit $=\Sigma \mathrm{Nx} \frac{\text { pengencer }}{\text { volumr }}$

Keterangan:

$\mathrm{N} \quad$ : Jumlah leukosit yang terhitung

\section{Perhitungan Diferensial Leukosit}

Perhitungan diferensial leukosit yaitu neutrofil, limfosit, dan monosit dilakukan dengan pengamatan pada preparat ulas darah. Metode pembuatan preparat ulas darah adalah sampel darah sebanyak $10 \mu \mathrm{L}$ diteteskan pada gelas objek. Gelas objek lain diletakkan pada gelas objek pertama yang terdapat sampel darah dengan sudut $45^{\circ}$ dari gelas objek pertama. Gelas objek yang menyentuh sampel darah digeser secara berlawanan arah sehingga membentuk lapisan tipis darah, setelah itu ulasan darah dikering udarakan. Ulasan darah yang sudah kering difiksasi menggunakan metanol selama 5 menit, lalu dikering udarakan. Ulasan darah selanjutnya diwarnai dengan pewarna Giemsa selama 20 menit. Preparat darah dibilas dan dicuci dengan akuades atau air mengalir. Jenis leukosit diamati dari 100 jumlah sel terhitung (Klontz, 2009). Jumlah diferensial leukosit dapat dihitung dengan rumus berikut (Hartika et al., 2014):

Neutrofil $=\frac{\sum \text { Neutrofil }}{100} \times 100 \%$

Limfosit $=\frac{\Sigma \text { Limfosit }}{100} \times 100 \%$

Monosit $=\frac{\Sigma \text { Monosit }}{100} \times 100 \%$

\section{Analisis Data}

Analisis sampel dilakukan secara insitu dan ex-situ. Analisis secara in-situ dilakukan di lokasi penelitian di kolam pembudidaya ikan patin, Kabupaten Sidoarjo, sedangkan analisa sampel secara ex-situ yaitu sampel yang diambil dari lokasi penelitian dianalisis di Laboratorium Parasit dan Penyakit Ikan Universitas Brawijaya Malang, dan Balai Karantina Ikan Kelas I Juanda, Surabaya. Selanjutnya data hasil analisis ex-situ dianalisis secara deskriptif.

\section{HASIL DAN PEMBAHASAN}

\section{Identifikasi Bakteri}

Hasil identifikasi bakteri yang dilakukan melalui pengamatan morfologi dan uji biokimia menunjukkan hasil karakteristik bakteri yang tersaji pada Tabel 1. 
Tabel 1. Karakteristik uji biokimia bakteri E. tarda.

\begin{tabular}{lcc}
\hline Parameter & Kontrol (+) & Sampel \\
\hline Gram & - & - \\
Katalase & + & + \\
Oksidase & - & - \\
Uji TSIA & K/A & K/A \\
Gas & - & - \\
$\mathrm{H}_{2} S$ & + & + \\
Motilitas & + & + \\
Indol & + & + \\
Ornithine decarboxylase & + & + \\
Citrate & - & - \\
Urea & - & - \\
Methyl Red & + & + \\
Voges Proskauer & - & - \\
Lysine Decarboxylase & + & + \\
Glukosa & + & + \\
Maltosa & + & - \\
Manitol & - & - \\
Sorbitol & - & - \\
Arabinose & - & - \\
Trehalose & - & - \\
Xilosa & - & + \\
\hline
\end{tabular}

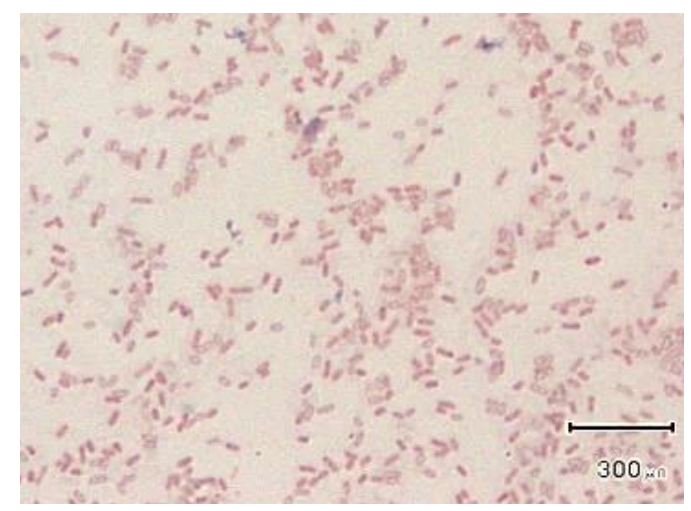

Gambar 1. Morfologi bakteri Edwardsiella tarda.
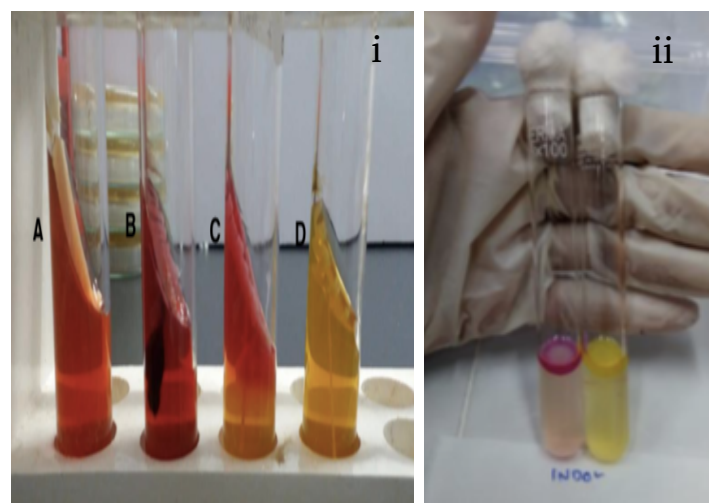

Gambar 2. (i) Hasil pengujian TSIA (A) TSIA yang belum diinokulasikan dengan bakteri; (B) $\mathrm{K} / \mathrm{K}, \mathrm{H}_{2} \mathrm{~S}$; (C) $\mathrm{K} / \mathrm{A}$; (D) A/A. (ii) Hasil uji indole.

Berdasarkan hasil uji biokimia menunjukkan bahwa isolat bakteri yang berasal dari sampel ikan merupakan bakteri Edwardsiella tarda dengan tingkat kecocokan 95\% dengan referensi dari Austin et al. (1995). 
Edwardsiella tarda merupakan golongan bakteri Gram negatif (Gambar 1), yang memiliki bentuk morfologi bakteri batang pendek, dapat menghasilkan indol dan $\mathrm{H}_{2} \mathrm{~S}$ (Gambar 2). Hal ini sesuai dengan pernyataan Hefdiyah dan Sovitri (2014), bahwa E. tarda merupakan bakteri Gram negatif yang memiliki bentuk batang, dapat menghasilkan indol, $\mathrm{H}_{2} \mathrm{~S}$, dan dapat menghasilkan enzim urease.

\section{Analisa Hematologi}

Hasil pengamatan dan perhitungan jumlah eritrosit, leukosit, limfosit, monosit, dan neutrofil ikan patin tersaji pada Gambar 3 dan Tabel 2.

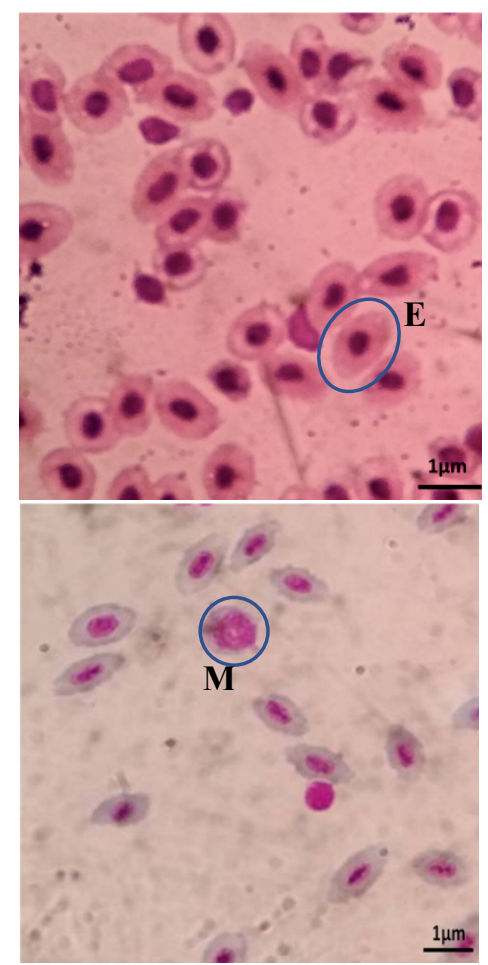

Jumlah rerata eritrosit pada ikan patin sakit (terinfeksi bakteri E. tarda) lebih rendah dibandingkan dengan ikan yang normal (tidak terinfeksi bakteri $E$. tarda). Menurut Grant (2015), jumlah eritrosit pada ikan patin yang normal berkisar antara $1,91-2,83 \times 10^{6} \mathrm{sel} / \mathrm{mm}^{3}$. Analisa hasil terkait jumlah eritrosit menunjukkan jumlah eritrosit yang rendah, hal ini menandakan ikan dalam keadaan anemia. Hal tersebut sesuai dengan pernyataan Susandi et al. (2017), bahwa anemia pada ikan terjadi karena adanya infeksi penyakit yang menyebabkan nilai eritrosit menurun sehingga suplai makanan ke sel, jaringan dan organ akan berkurang, dan proses metabolisme ikan menjadi terhambat.

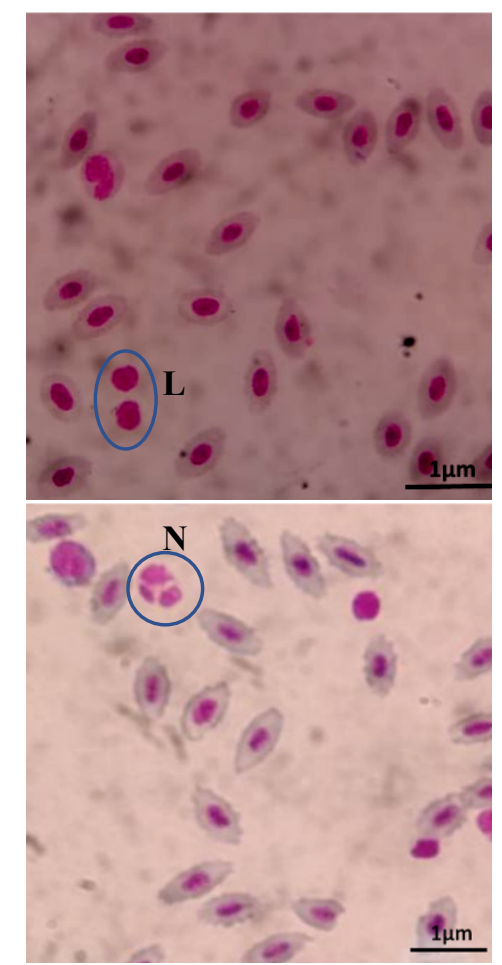

Gambar 3. Apusan darah. $\mathrm{E}=$ Eritrosit, $\mathrm{L}=$ Limfosit, $\mathrm{M}=$ Monosit, dan $\mathrm{N}=$ Neutrofil.

Tabel 2. Rerata jumlah eritrosit, leukosit, limfosit, monosit, dan neutrofil ikan patin.

\begin{tabular}{lrc}
\hline Parameter & Ikan patin normal & Ikan patin terinfeksi $E$. tarda \\
\hline Eritrosit $\left(10^{6} \mathrm{sel} / \mathrm{mm}^{3}\right)$ & $2,480 \pm 0.032$ & $1,695 \pm 0,041$ \\
Leukosit $\left(10^{4} \mathrm{sel} / \mathrm{mm}^{3}\right)$ & $3,460 \pm 0.087$ & $7,795 \pm 0,095$ \\
Limfosit $(\%)$ & $80,38 \pm 0.34$ & $52,15 \pm 0.26$ \\
Monosit (\%) & $12,85 \pm 0.12$ & $33,61 \pm 0.52$ \\
Neutrofil (\%) & $6,77 \pm 0.28$ & $14,24 \pm 0.47$ \\
\hline
\end{tabular}

Leukosit atau sel darah putih merupakan komponen sel darah yang mengandung inti. Leukosit memiliki peran penting dalam pertahanan tubuh dari infeksi patogen seperti bakteri. Pada ikan patin yang terinfeksi bakteri 
menunjukkan nilai rerata leukosit lebih tinggi dibandingkan ikan patin yang normal. Menurut Hartika et al. (2014), jumlah leukosit ikan normal adalah 2-5 $\times$ $10^{4} \mathrm{sel} / \mathrm{mm}^{3}$. Data hasil penelitian menunjukkan tingginya jumlah leukosit, hal ini merupakan salah satu tanda adanya infeksi dan ikan berusaha meningkatkan daya tahan tubuhnya. Hal ini didukung pernyataan Maftuch et al. (2012), bahwa peningkatan jumlah sel darah putih terjadi karena ikan berusaha meningkatkan daya tahan tubuhnya dari infeksi bakteri, sehingga leukosit bergerak aktif menuju tempat yang terkena infeksi.

Pengamatan diferensial leukosit dilakukan untuk mengetahui perbedaan persentase komponen sel leukosit yang terdiri dari limfosit, monosit dan neutrofil. Menurut Rustikawati (2012), limfosit berperan dalam sistem kekebalan spesifik yang dapat melindungi tubuh dari infeksi patogen, monosit berperan penting untuk memfagosit antigen yang masuk ke dalam tubuh dan memberikan informasi tentang infeksi penyakit kepada leukosit, sedangkan neutrofil merupakan jenis leukosit yang berperan dalam mekanisme pertahanan tubuh yang bekerja sebagai respons adanya infeksi dalam tubuh.

Jumlah limfosit ikan patin normal lebih tinggi dibandingkan dengan jumlah limfosit ikan patin yang terinfeksi $E$. tarda. Hal ini sesuai dengan pernyataan Preanger et al. (2016), bahwa persentase limfosit ikan patin normal berkisar antara $71,12-82,88 \%$. Berdasarkan data hasil penelitian menunjukkan rendahnya jumlah limfosit pada ikan patin yang terinfeksi E. tarda berhubungan dengan penurunan daya tahan tubuh ikan. Menurut Mahasri et al. (2011), menurunnya jumlah limfosit dapat menurunkan dosis antibodi sehingga menyebabkan meningkatnya infeksi penyakit. Hal ini diperkuat pendapat Rustikawati (2012), bahwa adanya peningkatan intensitas infeksi oleh patogen tertentu akan memicu kebutuhan limfosit dan mengakibatkan terjadinya pengurangan sel limfosit.

Jumlah monosit pada ikan patin yang terinfeksi E. tarda lebih tinggi daripada pada ikan patin normal. Tingginya jumlah monosit berkaitan dengan respons daya tahan tubuh untuk melawan infeksi penyakit. Menurut Lukistyowati et al. (2007), jumlah monosit ikan patin normal berkisar antara 5-13\%.

Ikan patin normal memiliki jumlah neutrofil lebih rendah dibandingkan ikan patin yang terinfeksi $E$. tarda. Tingginya jumlah neutrofil pada ikan patin yang terinfeksi $E$. tarda mengindikasikan adanya respons sistem kekebalan tubuh untuk melawan infeksi. Hal ini sesuai dengan pernyataan Utami et al. (2013), bahwa peningkatan jumlah neutrofil merupakan akibat dari mekanisme kekebalan tubuh yang bekerja sebagai respons adanya infeksi dalam tubuh. Peningkatan jumlah neutrofil pada ikan menunjukkan adanya aktivitas sel neutrofil dalam menyerang antigen (patogen) yang masuk ke dalam tubuh yang menunjukkan terjadinya proses fagositosis.

\section{KESIMPULAN}

Kondisi kesehatan ikan patin dapat dilihat melalui pemeriksaan darah. Ikan patin yang terinfeksi bakteri Edwardsiella tarda menunjukkan kondisi kesehatan yang kurang baik, yang ditunjukkan dari peningkatan nilai leukosit, monosit, dan neutrofil sebagai bentuk respons kekebalan tubuh terhadap infeksi bakteri.

\section{UCAPAN TERIMA KASIH}

Terima kasih kami ucapkan kepada Universitas Brawijaya dan Balai Karantina Ikan Kelas I Juanda, Surabaya atas dukungan dan bantuan yang diberikan untuk menyelesaikan penelitian ini.

\section{DAFTAR PUSTAKA}

Austin, B., Austin, D.A. dan Munn, C.B., 1995. Bacterial fish pathogens: Disease in farmed and wild fish. 
Reviews in Fish Biology and Fisheries, 5(1), pp. 123-124. https://doi.org/10.1007/978-14020-6069-4.

Blaxhall, P.C. dan Daisley, K.W., 1973. Routine haematological methods for use with fish blood. Journal of fish biology, 5(6), pp. 771-781. https://doi.org/10.1111/j.10958649.1973.tb04510.x.

Grant, K.R., 2015. Fish hematology and associated disorders. Veterinary Clinics: Exotic Animal Practice, 18(1), pp. 83-103. https://doi.org/ 10.1016/j.cvex.2014.09.007.

Hardi, D. dan Handayani, E., 2015. Parasit biota akuatik. Mulawarman University Press. Samarinda. 110 p. https://repository.unmul.ac.id/bitst ream/handle/123456789/1295/file _1021900025.pdf? sequence $=1 \&$ isA llowed $=\mathrm{y}$.

Hartika, R., Mustahal, M. dan Putra, A.N., 2014. Gambaran darah ikan nila (Oreochromis niloticus) dengan penambahan dosis prebiotik yang berbeda dalam pakan. Jurnal Perikanan dan Kelautan, 4(4). http://dx.doi.org/10.33512/jpk.v4i 4.174.

Hefdiyah, H. dan Shovitri, M., 2014. Potensi isolat bakteri Edwardsiella dan Corynebacterium dari Pulau Poteran Sumenep sebagai pelarut fosfat. Jurnal Sains dan Seni ITS, 3(2), pp. E75-E79. https://doi.org/ 10.12962/j23373520.v3i2.6910.

Klontz, G.W., 2009. Fish hematology. Ace Learning Company. California. 243 p.

Lukistyowati, I., Windarti dan Riauwaty, M., 2007. Analisis hematologi sebagai penentu status kesehatan ikan air tawar di Pekanbaru. Fakultas Perikanan dan Ilmu Kelautan Universitas Riau. Pekanbaru. Jurnal Akuatika, 2(2), pp. 1-14.

Maftuch, M., Nursyam, H. dan Sukarni, S., 2012. Kajian penggunaan Ciprofloxacin terhadap hematologi ikan botia (Botia macracanthus,
Bleeker) yang diinfeksi bakteri Aeromonas hydrophila. The Journal of Experimental Life Science, 2(2), pp.65-69. http://dx.doi.org/10. 21776/ub.jels.2012.002.02.02.

Mahasri, G., Widyastuti, P. dan Sulmartiwi, L., 2011. Gambaran leukosit darah ikan koi (Cyprinus carpio) yang terinfestasi Ichthyophthirius multifiliis pada derajat infestasi yang berbeda dengan metode kohabitasi [Leukocyte profil of koi fish (Cyprinus carpio) which infested by Ichthyophthirius multifiliis on the different infestation degree with cohabitation method]. Jurnal Ilmiah Perikanan dan Kelautan, 3(1), pp. 91-96. http://dx.doi.org/ 10.20473/jipk.v3i1.11629.

Nabib, R. dan Pasaribu, F.H., 1989. Patologi dan penyakit ikan. Departemen Pendidikan dan Kebudayaan. Direktorat Jenderal Pendidikan Tinggi. Pusat Antar Universitas Bioteknologi. Institut Pertanian Bogor. UPT Produksi Media Informasi LSI. IPB. Bogor.

Nadirah, M., Najiah, M. dan Teng, S.Y., 2012. Characterization of Edwardsiella tarda isolated from Asian seabass, Lates calcarifer. International Food Research Journal, 19(3), pp. 1247-1252. http://www. ifrj.upm.edu.my/19\%20(03)\%2020 12/(63)\%20IFRJ\%2019\%20(03)\% 202012\%20Nadirah.pdf

Oktafa, U., Suprastyani, H., Handayani, S., Gumala, G.A., Fatikah, N.M., Wahyudi, M., Farida, A. dan Pratama, R., 2017. Pengaruh pemberian bakteri Lactobacillus plantarum terhadap histopatologi dan hematologi ikan patin jambal (Pangasius djambal) yang diinfeksi bakteri Edwarsiella tarda. JFMRJournal of Fisheries and Marine Research, 1(1), pp. 31-38. http:// dx.doi.org/10.21776/ub.jfmr.2017. 001.01.6.

Preanger, C., Utama, I.H. dan Kardena, I.M., 2016. Gambaran ulas darah 
ikan lele di Denpasar Bali. Indonesia Medicus Veterinus, 5(2), pp. 96-103. https://ojs.unud.ac.id/index.php/i $\mathrm{mv} /$ article/view/22876.

Rustikawati, I., 2012. Efektivitas ekstrak Sargassum sp. terhadap diferensiasi leukosit ikan nila (Oreochromis niloticus) yang diinfeksi Streptococcus iniae. Jurnal Akuatika, 3(2). http://jurnal.unpad.ac.id/ akuatika/article/view/1609.

Samsisko, R.L.W, Suprapto, H. dan Sigit, S. 2013. Hematological response of humpback grouper fish (Cromileptes altivelis) in different temperatures of media. Journal of Aquaculture and Fish Health. 1(1), pp. 1-13. http://journal.unair.ac.id/downloa d-fullpapers-aquaculture5590ed f674full.pdf.

Sugiani, D., Sukenda, S., Harris, E. dan Lusiastuti, A.M., 2012. Pengaruh ko-infeksi bakteri Streptococcus agalactiae dengan Aeromonas hydrophila terhadap gambaran hematologi dan histopatologi ikan tilapia (Oreochromis niloticus). Jurnal Riset Akuakultur, 7(1), pp. 85-91. https://doi.org/10.15578/ jra.7.1.2012.85-91.

Susandi, F., Mulyana, M. dan Rosmawati, R., 2017. Peningkatan imunitas benih ikan gurame (Osphronemus gouramy Lac.) terhadap bakteri Aeromonas hydrophila menggunakan Rosella (Hibiscus sabdariffa L.). JURNAL MINA SAINS, 3(2), pp. 1-13. http://dx.doi.org/ 10.30997/jms.v3i2.889.

Tan, Y.P., Zheng, J., Tung, S.L., Rosenshine, I. dan Leung, K.Y., 2005. Role of type III secretion in Edwardsiella tarda virulence. Microbiology, 151(7), pp. 23012313. https://doi.org/10.1099/mic. 0.28005-0.

Utami, D.T., Prayitno, S.B., Hastuti, S. dan Santika, A., 2013. Gambaran parameter hematologis pada ikan nila (Oreochromis niloticus) yang diberi vaksin DNA Streptococcus iniae dengan dosis yang berbeda.
Journal of Aquaculture Management And Technology, pp. 7-20. https:// ejournal3.undip.ac.id/index.php/ja $\mathrm{mt} /$ article/view/4803/4635. 